\title{
JET FUEL PRICE VARIATIONS AND MARKET VALUE: A FOCUS ON LOW-COST AND REGULAR AIRLINE COMPANIES
}

\author{
Barbara GAUDENZI ${ }^{1}$, Alessandro BUCCIOL ${ }^{2}$ \\ ${ }^{1}$ Department of Business Administration, University of Verona, \\ Via Cantarane, 24, 37129 Verona, Italy \\ ${ }^{2}$ Department of Economics, University of Verona, Via Cantarane, \\ 24, 37129 Verona, Italy \\ E-mails: 'barbara.gaudenzi@univrit (correspondingauthor); ${ }^{2}$ alessandro.bucciol@univr.it
}

Received 07 January 2016; accepted 03 July 2016

\begin{abstract}
We analyze the relationship between dynamics to stock prices and jet fuel prices, conditional on financial and company-specific variables, in the airline sector. In particular, our contribution to the literature is in the comparison between regular and low-cost airline companies. We run a set of fixed-effect regressions where the dependent variable, the stock daily return of the airline company (observed between 2008 and 2014) is regressed over three sets of explanatory variables (financial, company-specific and time variables). While large and small companies provide similar results, we find that the company price return - among different variables - correlates only with the jet fuel return and the stock market return. Our work also suggests that there is a difference between regular and low-cost companies. We speculate that this possibly arises because low-cost companies stock-pile in a more efficient way, which depends less on current jet fuel price. Our evidence then sheds light on the efficiency of the low-cost model and may suggest to export part of its practice among regular airline companies.
\end{abstract}

Keywords: jet fuel price volatility, low-cost airlines, market value, airline sector, risk management, stock price.

JEL Classification: M20, G10.

\section{Introduction}

Crude oil is a basic commodity for many companies, and represents a significant fraction of their total spend. For this reason, the variability of crude oil prices is a key issue for the management and planning of organizations.

The goal of this paper is to better understand how oil price variations may affect the organization's balance sheet in one sector that is vulnerable to the dynamics of oil prices. We chose the airline industry because it is particularly exposed to prices of jet fuel, which is one of its main inputs. In particular, we look at the correlation between oil prices and market values of companies. We are interested in learning whether there 
is a negative correlation between company values and jet fuel prices and, in particular, how and why this correlation may vary among low-cost companies or among regular companies. We aim at providing managers with practical directions about how oil price movements can differently affect regular companies or low-cost companies, which may have different procurement strategies and risk capacity.

Other works in the literature already study the relation between company values and oil prices (see, e.g., Faff, Brailsford 1999; Carter et al. 2006; Nandha et al. 2013). However, to the best of our knowledge, with Lu et al. (2012) we are the first to focus on the distinction between low-cost and regular companies in the airline sector.

We focused our analysis on the US airline industry, which can assure a larger number of observations and generalizable results. In particular, we analyzed the eight airline companies currently listed in the US market. In fact, the major worldwide players operate there, and the low-cost sector is established in this area since many years. For each company we have information on daily value returns, size and other balance-sheet data for a period ranging between 2008 and 2014. The analysis is then performed by means of fixed-effect panel regressions on US airline stock price daily returns; our analysis investigates how company market returns are correlated with the general stock market index and jet fuel market returns. Considering both regular and low-cost companies, and searching for potential differences across them, should indicate what other factors - like management strategies - may influence the correlation between company returns and fuel price dynamics.

The remainder of the paper is organized as follows. Section 1 provides a review of the literature on the connection between oil price movements and macro-economic and company-specific performance, and sets our research hypotheses. Section 2 describes the data, while Section 3 shows the model, results and our interpretation, and Section 4 reports managerial implications. A final section concludes the paper by discussing limitations and future extensions of this work.

\section{Related literature: oil price variations}

\subsection{Effects on financial performance}

Recent crude-oil price movements - close to record levels (see Figure 1 below) - as well as dynamics in the oil production and frequent cases of supply disruptions confirm that oil price risk represents a key issue for organizations and governments (see BP 2014).

The relationships between oil-price variations and financial and economic variables have been largely described in the literature (see Table 1): authors have examined how oil-price shocks affect economic performance (Cunado, Perez de Gracia 2003), business cycle dynamics (Rogoff 2006), inflation and recessions (Kim, Loungani 1992; O'Neill et al. 2008), exchange rates (Chen, S. S., Chen, H. C. 2007), and economic growth (Cologni, Manera 2008). 


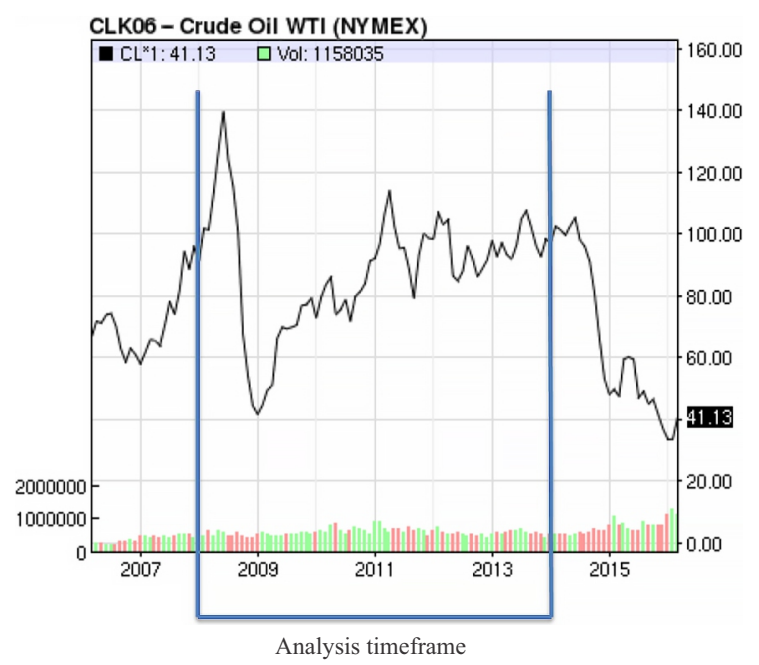

Fig. 1. Crude oil price dynamics

Source: www.nasdaq.com

Table 1. Relationships between oil-price variations, financial and economic variables

\begin{tabular}{|c|c|c|}
\hline Oil-price shocks affect & Studies in the literature & $\begin{array}{l}\text { Studies on airline } \\
\text { companies }\end{array}$ \\
\hline Economic performance & $\begin{array}{l}\text { Cunado and Perez de Gracia (2003); } \\
\text { Jimenez-Rodriguez and Sanchez (2005) }\end{array}$ & $\begin{array}{l}\text { Gal-Or (2011); Hoffer } \\
\text { et al. (1996) }\end{array}$ \\
\hline Business cycle dynamics & Rogoff (2006) & \\
\hline Inflation and recessions & Kim and Loungani (1992) & \\
\hline Exchange rates & Chen and Chen (2007); Chang et al. (2013) & \\
\hline Stock price returns & Sadorsky (2001) & Nandha et al. (2013) \\
\hline Economic growth & Cologni and Manera (2008) & \\
\hline Country-based studies & $\begin{array}{l}\text { Park and Ratti (2007) for USA and Europe; } \\
\text { O'Neill et al. (2008) for major developed } \\
\text { countries; Arouri and Rault (2012) for Gulf } \\
\text { Cooperation Council Countries; Kumar } \\
\text { (2014) for India; El-Sherif et al. (2005) } \\
\text { for UK; Camarero and Tamarit (2002) for } \\
\text { Spain; Cong et al. (2008) for China }\end{array}$ & $\begin{array}{l}\text { Carter et al. (2006), } \\
\text { Turner and Lim (2015) } \\
\text { for USA; Avenali et al. } \\
\text { (2015) for Europe }\end{array}$ \\
\hline
\end{tabular}

Recently, the literature has examined the impact of oil prices on the stock market and exchange rates, using data from either single countries or multiple countries. For example, Park and Ratti (2007) analyze these dynamics in the US and Europe; O'Neill et al. (2008) focus on the so-called major developed countries, and Arouri and Rault (2012) on the Gulf Cooperation Council Countries.

The study conducted by Park and Ratti (2007) in a period between 1986 and 2005 shows that oil price shocks account for a statistically significant $6 \%$ of the volatility in real 
stock returns. For many European countries, but not for the US, increased volatility of oil prices significantly depresses real stock returns. The contribution of oil price shocks to the variability in real stock returns in the US and most other countries is actually greater than that of interest rates.

Going ahead, O'Neill et al. (2008) examine, among other things, whether the recent increase in world oil prices has affected stock market returns focusing in the major OECD countries between 2003 and 2006. They find that the impact of higher oil prices on stock market returns differs among countries. While higher oil prices are found to adversely affect stock market returns in the US, the UK and France, the effects are positive in Canada and Australia as these countries are large exporters of energy resources. O'Neill et al. (2008) also stress that the situation is complicated by the ability of organizations to pass on the cost increases to consumers or by the extent to which companies hedge against oil price risk.

Other authors have focused on single countries like - for example - India (see Kumar 2014), the UK (El-Sherif et al. 2005), Spain (Camarero, Tamarit 2002), or China (Cong et al. 2008). For instance Kumar (2014) supports the view that, between 1986 and 2012, there is a relationship between crude oil prices in the international market (measured by the price of West Texas Intermediate, or WTI), Indian rupee / US dollar exchange rate and the Indian stock market index.

El-Sherif et al. (2005) are among the few authors investigating the relationship between the price of crude oil and equity value. The paper is focused on the oil and gas sector and used data of the largest oil producer in the European Union. The evidence indicates that the relationship is always positive, often highly significant and reflects the direct impact of volatility in the price of crude oil on share values within this sector.

Also Sadorsky (2001) sheds light on the fact that crude oil has large and significant impacts on stock price returns. In particular, an increase in the market or oil price factor increases the return to Canadian oil and gas stock prices while an increase in exchange rates or the term premium decreases the return to Canadian oil and gas stock prices. Furthermore, the oil and gas sector is less risky than the market and its movements are pro-cyclical. The author then suggested that Canadian oil and gas stocks may not be a good hedge against inflation.

\subsection{Effects on company performance in the airline industry}

The focus of this paper is the airline sector and the impact of jet fuel price dynamics on organizations' returns. We investigate this sector because airline companies are significantly exposed to oil price movements (jet fuel in particular). In this industry the variations of fuel prices significantly affect companies' profits (Avenali et al. 2015), but these correlations have been only partially investigated so far. The study proposed by Elyasiani et al. (2011) highlights that in those sectors that are oil-users - like air transportation - price dynamics have a great impact on the sector returns. Hileman and Stratton (2014) investigated the feasibility of alternative energy sources in the air transportation industry. 
Fuel prices and stock market factors affect industries' returns differently, for various reasons. In the airline industry there are some characteristics that indicate how fuel price dynamics can affect returns (Table 2).

The first characteristic is the percentage of expenditures allocated to the commodity (Cigolini, Rossi 2010), which is essentially fuel in the airline market, and accounts for a significant percentage of spend.

Table 2. Airlines' characteristics and effects of fuel price dynamics

\begin{tabular}{|c|c|c|}
\hline Airlines' characteristics & Studies in the literature & $\begin{array}{l}\text { Studies on the effects of fuel price } \\
\text { dynamics on companies' outcome }\end{array}$ \\
\hline $\begin{array}{l}\text { High percentage of expenditures } \\
\text { allocated to jet fuel }\end{array}$ & $\begin{array}{l}\text { Cigolini and Rossi (2009); } \\
\text { Marshall et al. (2015) }\end{array}$ & Not yet investigated. \\
\hline $\begin{array}{l}\text { The size of the organizations } \\
\text { (low-cost and regular companies) }\end{array}$ & Hendricks et al. (2009) & $\begin{array}{l}\text { Lu et al. (2012). The present study } \\
\text { aims at filling this gap. }\end{array}$ \\
\hline Use of hedging techniques & $\begin{array}{l}\text { Rittenber and Martens } \\
\text { (2012); Hendricks and } \\
\text { Singhal (2003); Carter } \\
\text { et al. (2006); Faff and } \\
\text { Brailsford (1999) }\end{array}$ & $\begin{array}{l}\text { Turner and Lim (2015) investigated } \\
\text { the most effective hedging } \\
\text { techniques, and Lim and Hong } \\
\text { (2014) examined the role of fuel } \\
\text { hedging in reducing airlines' } \\
\text { operating costs. Treanor et al. } \\
\text { (2014) investigate the effects of } \\
\text { both financial and operational } \\
\text { hedging on jet fuel exposure in } \\
\text { the U.S. airline industry. }\end{array}$ \\
\hline $\begin{array}{l}\text { The ability to transfer the } \\
\text { commodity price risk to the final } \\
\text { product price paid by customers }\end{array}$ & Granados et al. (2011) & $\begin{array}{l}\text { Low-cost and regular companies } \\
\text { may adopt different strategies than } \\
\text { transferring costs (Mulhall and } \\
\text { Bryson 2014; Hoffer et al. 1996). }\end{array}$ \\
\hline $\begin{array}{l}\text { Production process management } \\
\text { and energy strategies }\end{array}$ & Hirshleifera et al. (2012) & $\begin{array}{l}\text { Alam et al. (1998); show evidence } \\
\text { that the choice about energy } \\
\text { can impact the stock market } \\
\text { performance. Tavassoli et al. } \\
\text { (2014) and Lee et al. (2015) } \\
\text { propose two models, which } \\
\text { describe productivity and efficieny } \\
\text { of airlines. }\end{array}$ \\
\hline
\end{tabular}

The second characteristic is the size of the organization and the marginal value of its products (Hendricks et al. 2009). In our study we focus on both large and medium companies, divided in two groups: low-cost and regular companies. The aim of the paper is to identify potential differences among these groups. The size and type of an organization may impact on its risk appetite and hedging strategies (Hendricks, Singhal 2003), that are likely to matter when it comes to dealing with fuel prices. In the airline sector, only Lu et al. (2012) indicate that, in general, the low-cost airlines, on average, are more efficient carriers than the full-service ones, but less efficient marketers. 
Several authors (Faff, Brailsford 1999; Naumann, Suhl 2013; Turner, Lim 2015) find that organizations can protect themselves against adverse movements in oil pricing through hedging using derivative instruments. Thus, a third characteristic is the capability to invest in hedging strategies when - for example - fuel prices are high and organizations' operating cash flows are low (Carter et al. 2006). More recently, Treanor et al. (2014) investigate the effects of both financial and operational hedging on jet fuel exposure in the U.S. airline industry. Specifically, they analyze two operational hedging strategies: the extent to which airlines operate different aircraft types and the degree to which airlines operate fuel-efficient fleets.

A fourth characteristic is the ability to transfer the commodity price risk to the final product price paid by customers (Gal-Or 2011). Final product prices were considered able to absorb the volatility of jet fuel, but the new competitive environment, due in particular to Internet technologies, has enhanced the ability of consumers to compare offer prices across suppliers, threatening the transferability of these costs (Granados et al. 2011). Related to this, low-cost and regular companies may adopt different strategies than transferring costs (Mulhall, Bryson 2014; Hoffer et al. 1996).

Finally, it is worth noticing that a fifth characteristic could play a role in the way fuel price dynamics can affect returns. The literature largely supports the idea that technical investments in efficiency have an impact on stock market returns. Analyzing eleven US airlines from 1970-1990, Alam and Sickles (1998) show evidence that the choices about energy (aircraft fuel), being part of the technical efficiency news that an organization can deliver to the market, can impact the stock market performance, therefore leading to excess returns.

Tavassoli et al. (2014) propose a model, which deals with shared inputs and non-storable feature of transportation service, measuring technical efficiency and service effectiveness. Lee et al. (2015) also describe the joint production of desirable and undesirable output production of airlines.

\subsection{The aim of the research}

The scope of the paper is to investigate whether there is a correlation between airline company values and jet fuel price dynamics. In particular, we focus on the differences among low-cost companies and regular companies based in USA, expanding other above-mentioned studies conducted in UK and Canada. We also aim at identifying some managerial implications and practical directions about how oil price movements can affect companies with different procurement strategies and risk capacity. Therefore, the scope of the research is to validate the following hypotheses:

HP1: we expect that there is a negative correlation between airline company values (stock price returns) and jet fuel price dynamics; and

HP2: we expect that the correlation between airline company values (stock price returns) and jet fuel price dynamics is larger for regular companies. 


\section{Data}

\subsection{Dataset}

We collected the time series of daily stock returns on all the airline companies listed in the US market. We selected US companies because they are the major players worldwide, and also because the low-cost sector is established in this area since many years ${ }^{1}$.

Eight companies are currently traded in the US stock market: Alaska Airlines (NYSE: ALK), Allegiant Air (NASDAQ: ALGT), American Airlines (NASDAQ: AAL), Delta Airlines (NYSE: DAL), Hawaiian Airlines (NASDAQ: HA), Jetblue Airways (NASDAQ: JBLU), Southwest Airlines (NYSE: LUV) and United Airlines (NYSE: UAL). Three of them (Allegiant Air, Jetblue Airways, and Southwest Airlines) are low-cost companies. In our empirical analysis we then aggregate the companies in two groups: low-cost and regular (i.e., non low-cost). It should be noted that the two groups are unbalanced, as the low-cost one is made of three companies while the regular one is made of five companies.

Moreover, we collected data on jet fuel daily price changes (Energy Information Administration 2015) and on three financial indicators (Freelunch 2015): the US stock market returns (S\&P500 index), and the yields on 3-month T-bills and 10-year T-bonds.

We also retrieved from MIT Airline Data Project (2015) annual business data specific to the balance sheet of each company. The purpose is to control for the size of the companies. In addition to the distinction between low-cost and regular companies we consider: total costs, the ratio between fuel costs and total costs, the Revenue Passenger per Mile (RPM) and the Available Seat Miles (ASM).

The sample period starts when all the eight companies are present in the stock market (i.e., at the beginning of 2008) and covers daily the years 2008-2014. However, during this period three important mergers have been made. To remove potential spurious effects due to these actions and their preparation, we exclude from the sample the years 2008-2009 for Delta Airlines (merged with Northwest Airlines), 2011-2014 for United Airlines (merged with Continental Airlines) and 2013-2014 for American Airlines (merged with US Airways). A robustness check available upon request, performed using the whole sample period for all the companies, supports and actually reinforces our benchmark results ${ }^{2}$.

\footnotetext{
${ }^{1}$ The first low-cost carrier in the world was called Pacific Southwest Airlines. It was established in 1949 with headquarters in San Diego.

${ }^{2}$ We also tried to develop the analysis in Section 3 with a different data structure: rather than working with a panel dataset, we worked with a time series dataset. This dataset was constructed by taking the sample average of each variable, conditional on time and the group (low-cost or regular). This way the unit of analysis is the group of low-cost / regular companies rather than each of the eight companies. The advantage of such analysis is to have a long sequence of data without gaps; the disadvantage is to reduce the number of observations to a larger extent. This notwithstanding, the results are essentially the same as in Section 3. The output is available upon request.
} 


\subsection{Summary statistics}

Figure 2 plots the time series of returns for the airline companies (low-cost and regular) as well as for jet fuel and the S\&P500 index. The series of low-cost and regular companies are highly correlated with each other (the correlation is 0.84 ); they also exhibit highly positive correlation with S\&P500 returns (the correlation is 0.38 for low-cost companies returns and 0.46 for regular companies) and moderately negative correlation with jet fuel returns (the correlation is -0.14 for low-cost companies and -0.17 for regular companies).

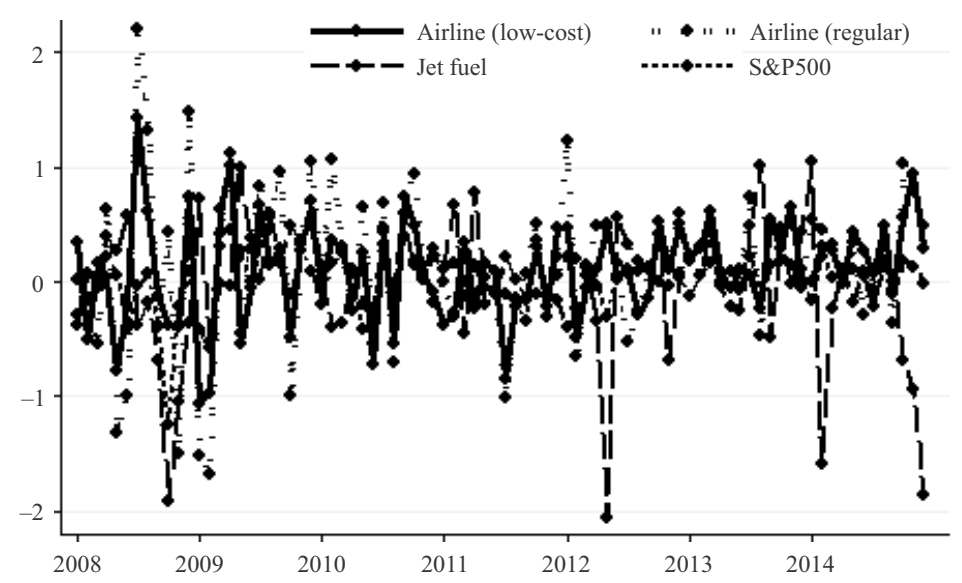

Fig. 2. Return series

Table 3 shows the average value of the variables used in the analysis, that we divide in "common" market variables and "specific" company variables. In line with both Hypothesis 1 and Hypothesis 2, it is interesting to note that the correlation between daily returns on stock prices and jet fuel prices is always negative and larger for regular companies. Low-cost companies are then less heavily affected by movements in jet fuel prices, possibly because the way they stock-pile is more efficient and depends less on current jet fuel price. In fact low-cost carriers typically face higher operating costs because changes in fuel costs disproportionately impact narrow-body, short-haul flying; it is then fundamental for them to implement strategies meant to limit fuel price variations.

One possible concern with this evidence is that the regular group includes companies that are far larger than the low-cost companies. In fact, these companies on average face larger total costs, RPM and ASM and have a smaller fuel/costs ratio (because costs are larger). For this reason the last column of Table 3 provides statistics for this same group but excluding the three largest companies, i.e., American Airlines, Delta Airlines, and United Airlines; to be included are thus Alaska Airlines and Hawaiian Airlines only. This new group is actually made of companies smaller than low-cost companies: in fact costs, RPM and ASM are lower in Column (3) than in Column (1). This notwithstanding, the correlation between stock and jet fuel price is still quantitatively larger than for low-cost companies. 
Table 3. Summary statistics

(1)

\begin{tabular}{|c|c|c|c|}
\hline Sample: & Low-cost & Regular & Regular, small \\
\hline \multicolumn{4}{|c|}{ Common } \\
\hline Jet fuel return & -0.044 & -0.037 & -0.044 \\
\hline S\&P 500 return & 0.022 & 0.030 & 0.022 \\
\hline 3-month yield & 0.276 & 0.223 & 0.276 \\
\hline 10-year yield & 2.811 & 2.746 & 2.811 \\
\hline \multicolumn{4}{|c|}{ Specific } \\
\hline Stock return & 0.110 & 0.144 & 0.145 \\
\hline Ln(total costs) & 14.427 & 15.205 & 14.088 \\
\hline Fuel/total costs & 0.596 & 0.536 & 0.497 \\
\hline $\operatorname{Ln}(\mathrm{RPM})$ & 3.134 & 3.822 & 2.655 \\
\hline $\operatorname{Ln}(\mathrm{ASM})$ & 3.328 & 4.011 & 2.843 \\
\hline \multicolumn{4}{|c|}{ Corr. Stock /Jet fuel } \\
\hline & -0.010 & -0.021 & -0.018 \\
\hline Observations & 5,205 & 7,177 & 3,470 \\
\hline
\end{tabular}

Note. All "specific" variables, apart from stock return, are statistically different between the low-cost and regular groups according t a t-test.

\section{Econometric analysis}

\subsection{Model}

We run fixed-effect panel regressions where the dependent variable, the daily airline stock return, is regressed over three sets of explanatory variables: financial variables, namely the same-day S\&P500 market return, jet fuel price change, 3-month and 10-year bond yields; company-specific variables, namely the previous-year (as reported in the balance sheets) total costs, the fuel cost/total cost ratio, the (log of) RPM and ASM; and time variables, as measured with month dummies. The equation can be summarized as follows, where $i$ denotes the airline company and $t$ the time:

$$
y_{i t}=\alpha_{i}+\beta F_{i t}+\gamma C_{i t}+\delta T_{i t}+\varepsilon_{i t} .
$$

In the e quation, the dependent variable $y$ measures the stock return, $F, C$ and $T$ are (respectively the financial, company-specific and time explanatory variables, $\alpha$ indicates the fixed company effects, $\beta$, yand $\delta$ are coefficients to be estimated and $\varepsilon$ is the error term. To account for potential heteroscedasticity, cross-sectional and serial correlation, we consider Driscoll-Kraay standard errors (for details see Driscoll, Kraay 1998). For serial correlation we consider a lag of five days (i.e., one week of trading activity); results do not vary if we take a different number of lags.

To test our research hypotheses (see Sub-section 1.3), we are interested in the estimate of the $\beta$ coefficients on the financial variables, and especially on the sign and size of the 
coefficients on S\&P500 and jet fuel returns. Specifically, we expect: $i$ ) the coefficients on S\&P500 returns to be above zero, to indicate positive correlation with airline stock returns; ii) the coefficients on jet fuel returns to be below zero, to indicate negative correlation with airline stock returns, to support HP1; iii) the coefficient on jet fuel returns for low-cost companies to be significantly closer to zero than regular companies, to indicate that stock returns are less influenced by jet fuel returns for low-cost companies than for regular companies, to support HP $2 .{ }^{3}$ The remaining explanatory variables are added as controls.

Regarding the company-specific variables, total costs are included to control for the size of the company, while the fuel/total costs ratio is added to consider the potential exposure of the company to fuel price changes. The last two company-specific indicators (RPM and ASM) are respectively standard measures of profitability and size in the airline market. The month dummies are expected to capture any existing seasonality, while the year effect is captured by the company-specific variables that are fixed within a year. These two sets of variables also help to control for the declining demand in the airline sector following the global recession.

The fixed-effect model provides consistent estimates of the coefficients provided that there is no correlation between the explanatory variables and the error term. This assumption can be violated when one or more explanatory variables are omitted from the regression equation; if such variables correlate with the explanatory variables included in the equation, the fixed-effect estimator is inconsistent. However, a fixed-effect model is more robust than alternative models for panel data because its estimates are still consistent when the omitted variables are time-invariant (for instance, in our context they could be variables on the specific management style of the companies). The reason is that the contribution of the omitted variables to the dependent variable is implicitly incorporated in the fixed effects.

\subsection{Results}

The analysis is performed separately for three groups of airline companies: low-cost (Allegiant Air, Jetblue Airways, and Southwest Airlines), regular (Alaska Airlines, American Airlines, Delta Airlines, Hawaiian Airlines, and United Airlines) and regular without the largest three companies (i.e., just Alaska Airlines and Hawaiian Airlines). We consider this third group to run a robustness check on the possibility that our results are otherwise biased by the larger size of American Airlines, Delta Airlines, and United Airlines.

Table 4 reports our benchmark estimates. The analysis suggests that, among the key dimensions, the airline company price return correlates only with the jet fuel return and the stock market return. Specifically, company returns grow between 1.1 and $1.5 \%$ when the S\&P500 index rises by $1 \%$ (thus more than proportionally) and fall between 0.2

\footnotetext{
${ }^{3}$ We also tried to add to the specification a quadratic term on jet fuel returns. Its coefficient is never significant, suggesting that the relation between company stock returns and jet fuel returns, if any, is linear.
} 
and $0.3 \%$ when jet fuel prices rise by $1 \%$ (thus less than proportionally). Hence airline company prices are more highly correlated with the S\&P500 index than with jet fuel prices. These results confirm HP1 and HP2.

It is interesting to note that regular companies show higher correlations in both cases: the marginal effect of a 1\% rise in the S\&P500 index is 1.500 for regular companies as opposed to 1.135 for low-cost companies, while the marginal effect of a $1 \%$ rise in jet fuel prices is -0.287 for regular companies as opposed to -0.193 for low-cost companies. In both cases, the difference is significant according to an F-test (60.75 with p-value $<0.01$ for S\&P500; 8.41 with p-value equal to 0.02 for jet fuel returns).

Table 4. Panel regression analysis

\begin{tabular}{|c|c|c|c|}
\hline & (1) & (2) & (3) \\
\hline Sample & Low-cost & Regular & Regular, small \\
\hline Jet fuel return & $\begin{array}{c}-0.193^{* *} \\
(0.028)\end{array}$ & $\begin{array}{c}-0.270 * * * \\
(0.043)\end{array}$ & $\begin{array}{c}-0.228^{* * *} \\
(0.041)\end{array}$ \\
\hline S\&P500 return & $\begin{array}{c}1.135^{* * * *} \\
(0.049)\end{array}$ & $\begin{array}{c}1.500^{* * * *} \\
(0.067)\end{array}$ & $\begin{array}{l}1.288^{* *} \\
(0.063)\end{array}$ \\
\hline 3-month yield & $\begin{array}{c}0.122 \\
(0.144)\end{array}$ & $\begin{array}{c}0.106 \\
(0.175)\end{array}$ & $\begin{array}{c}0.148 \\
(0.133)\end{array}$ \\
\hline 10-year yield & $\begin{array}{l}-0.001 \\
(0.080)\end{array}$ & $\begin{array}{c}0.081 \\
(0.114)\end{array}$ & $\begin{array}{c}0.007 \\
(0.115)\end{array}$ \\
\hline $\operatorname{Ln}($ total costs $)$ & $\begin{array}{c}0.142 \\
(0.297)\end{array}$ & $\begin{array}{c}0.182 \\
(0.725)\end{array}$ & $\begin{array}{l}-0.934 \\
(1.217)\end{array}$ \\
\hline Fuel/total costs & $\begin{array}{c}0.173 \\
(0.639)\end{array}$ & $\begin{array}{l}-0.180 \\
(1.068)\end{array}$ & $\begin{array}{c}0.786 \\
(1.733)\end{array}$ \\
\hline $\operatorname{Ln}(\mathrm{RPM})$ & $\begin{array}{l}-0.763 \\
(1.526)\end{array}$ & $\begin{array}{c}-0.418 \\
(1.357)\end{array}$ & $\begin{array}{l}-0.961 \\
(1.569)\end{array}$ \\
\hline $\operatorname{Ln}(\mathrm{ASM})$ & $\begin{array}{c}0.768 \\
(1.430)\end{array}$ & $\begin{array}{c}0.430 \\
(1.570)\end{array}$ & $\begin{array}{c}2.209 \\
(2.106)\end{array}$ \\
\hline Constant & $\begin{array}{l}-2.322 \\
(3.554)\end{array}$ & $\begin{array}{l}-2.854 \\
(7.808)\end{array}$ & $\begin{array}{c}8.846 \\
(13.663)\end{array}$ \\
\hline Month dummies & YES & YES & YES \\
\hline Fixed company effects & YES & YES & YES \\
\hline F-test for month dummies & {$[0.644]$} & {$[0.576]$} & {$[0.721]$} \\
\hline F-test for fixed effects & {$[0.776]$} & {$[0.940]$} & {$[0.313]$} \\
\hline F-test for autocorrelation & {$[0.697]$} & {$[0.777]$} & {$[0.532]$} \\
\hline Observations & 5,205 & 7,177 & 3,470 \\
\hline Within-group R-squared & 0.280 & 0.264 & 0.289 \\
\hline
\end{tabular}

Note. Low-cost companies: Allegiant Air, Jetblue Airways, Southwest Airlines; Regular companies: Alaska Airlines, American Airlines, Delta Airlines, Hawaiian Airlines, United Airlines; Regular, small companies: Alaska Airlines, Hawaiian Airlines. Driscoll-Kraay standard errors in round parentheses; $\mathrm{p}$-values in squared parentheses; $* * * \mathrm{p}<0.01, * * \mathrm{p}<0.05, * \mathrm{p}<0.1$. 
No other coefficient of the regression is significantly different in the two groups of companies at usual significance levels (F-tests available upon request). All the above results are confirmed if we compare low-cost companies with small regular companies rather than all the regular companies (i.e., if we compare Column (1) with Column (3) rather than Column (2)).

The fit of the model is relatively high (the within-group R-squared statistic is between 0.26 and 0.29 ); F-tests accept the hypothesis of no significance of the coefficients on the month dummies and the fixed company effects. In the first case, this means that airline stock returns exhibit no further seasonality in addition to the one already captured by the correlation with jet fuel and market returns; in the second case, it means that airline stock returns are not systematically different across companies. The outcome of this test also indicates that it is not necessary to use a fixed-effect model and we could instead use an OLS estimator pooling the data as if they were cross-sectional. However, we chose to report fixed-effect estimates to be conservative since, as mentioned in Subsection 3.1, only this model is consistent when time-invariant explanatory variables are omitted from the specification.

A final test, reported in the bottom part of Table 4, checks for the presence of autocorrelation in the residuals of the fixed-effect model. The test, developed by Wooldridge (2002), concludes that there is no remaining autocorrelation in the residuals; our fixedeffect model is then appropriate and needs no further correction.

\section{Managerial Implications}

Our interpretation is that the correlation for regular company prices is higher with the stock market as these companies are more actively traded, and is higher with jet fuel prices as they may implement strategies less adequate to hedge against fuel price volatility. The distance between low-cost and regular companies shrinks, but does not change sign, when we focus on the restricted set of the smaller regular companies.

Therefore, a practical implication for procurement managers and financial managers of low-cost companies is that investing on strategy of efficiency, such as the use of jet fuel on aircrafts and the reduction of the stock units, allows them to be less heavily affected by movements in jet fuel prices. Efficiency represents for these companies a prevention strategy against the financial risk related to fuel price movements. Conversely, regular companies are more exposed to jet fuel price variations, due to the larger use of fuel volumes and stocks. As a consequence, managers of regular companies should invest more on risk mitigation strategies - in order to reduce the financial consequences of the risks related to the fuel price variations.

\section{Conclusions}

In this paper we analyze the relationship between fuel price dynamics, financial variables and company-specific variables in the airline sector. In particular, our contribution is on the comparison between regular and low-cost companies. Our analysis, based on regressions of daily returns of airline companies traded in the US market between 2008 
and 2014, suggests that company price returns correlate only with variations in the general stock market index and jet fuel prices. In particular, the correlation of price returns is strongly positive with the general stock market index, and weakly negative with jet fuel prices. Interestingly, both correlations are smaller on low-cost companies than on regular companies. The results are obtained after controlling for company-specific characteristics as well as time effects. The findings hold true also after restricting the comparison between companies of similar size.

Our results indicate that - across different organization variables - the size does not influence the above-mentioned correlation. While for all the companies jet fuel accounts for a high fraction of total spend, the different management strategies adopted by lowcost and regular companies - such as procurement strategy and efficiency - seem to influence the exposure to jet fuel price variations.

However, a note of caution is necessary before commenting on our findings. We ran a relatively simple analysis on the correlation between returns to the stock price of airline companies and jet fuel price. We may be missing from the specification important unobserved time-varying explanatory variables that could bias our results. Moreover, although we tried to be careful on this issue, the period we consider experienced several mergers that could have influenced the prices of the involved airlines.

Keeping in mind the above-mentioned limitations, we speculate that the risk management strategies adopted by airlines companies can smooth the effects of jet fuel price variations, with a direct impact on the companies' returns. When effective risk mitigation strategies are adopted, the residual effect of oil price volatility on revenues may be unimportant. Airline companies typically invest intensively in different risk mitigation strategies - such as hedging, passing price increase to customers or contractual agreements. As a future research direction we aim at extending our analysis to the risk mitigation strategies adopted by the companies.

Finally, strategic decisions about if and how to transfer fuel price increases to customers - for example through flight ticket price variations - may influence the correlation between jet fuel price dynamics and companies' revenues. A second future research direction may be the analysis of the pricing strategies adopted by the companies towards passengers.

\section{References}

Alam, I. M. S.; Sickles, R. C. 1998. The relationship between stock market returns and technical efficiency innovations: evidence from the US airline industry, Journal of Productivity Analysis 9(1): 35-51. https://doi.org/10.1023/A:1018368313411

Arouri, M. E. H.; Rault, C. 2012. Oil prices and stock markets in GCC countries: empirical evidence from panel analysis, International Journal of Finance and Economics 17(3): 242-253. https://doi.org/10.1002/ijfe.443

Avenali, A.; D’Alfonso, T.; Leporelli, C.; Matteucci, G.; Nastasi, A.; Reverberi, P. 2015. An incentive pricing mechanism for efficient airport slot allocation in Europe, Journal of Air Transport Management 42: 27-36. https://doi.org/10.1016/j.jairtraman.2014.07.009

BP. 2014. Statistical review of world energy [online], [cited 30 February 2015]. Available from Internet: http:/www.bp.com/en/global/corporate/about-bp/energy-economics/statistical-reviewof-world-energy/review-by-energy-type/oil/oil-prices.html 
Camarero, M.; Tamarit, C. 2002. Oil prices and Spanish competitiveness: a cointegrated panel analysis, Journal of Policy Modeling 24(6): 591-605.

https://doi.org/10.1016/S0161-8938(02)00128-X

Carter, D. A.; Rogers, D. A.; Simkins, B. J. 2006. Hedging and value in the U.S. airline industry, Journal of Applied Corporate Finance 18(4): 21-33.

https://doi.org/10.1111/j.1745-6622.2006.00107.x

Chen, S. S.; Chen, H. C. 2007. Oil prices and real exchange rates, Energy Economics 29(3): 390-404. https://doi.org/10.1016/j.eneco.2006.08.003

Cigolini, R.; Rossi, T. 2010. Managing operational risks along the oil supply chain, Production Planning and Control 21(5): 452-467. https://doi.org/10.1080/09537280903453695

Cologni, A.; Manera, M. 2008. Oil prices, inflation and interest rates in a structural cointegrated VAR model for the G-7 countries, Energy Economics 30(3): 856-888.

https://doi.org/10.1016/j.eneco.2006.11.001

Cong, R.-G.; Wei, Y. M.; Jiao, J. L.; Fan, Y. 2008. Relationships between oil price shocks and stock market: an empirical analysis from China, Energy Policy 36(9): 3544-3553.

https://doi.org/10.1016/j.enpol.2008.06.006

Cunado, J.; Perez de Gracia, F. 2003. Do oil price shocks matter? Evidence for some European countries, Energy Economics 25(2): 137-154. https://doi.org/10.1016/S0140-9883(02)00099-3

Driscoll, J. C.; Kraay, A. C. 1998. Consistent covariance matrix estimation with spatially dependent panel data, Review of Economics and Statistics 80: 549-560.

https://doi.org/10.1162/003465398557825

El-Sherif, I.; Brown, D.; Burton, B.; Nixon, B.; Russell, A. 2005. Evidence on the nature and extent of the relationship between oil prices and equity values in the UK, Energy Economics 27(6): 819-830. https://doi.org/10.1016/j.eneco.2005.09.002

Elyasiani, E.; Mansur, I.; Odusami, B. 2011. Oil price shocks and industry stock returns, Energy Economics 33(5): 966-974. https://doi.org/10.1016/j.eneco.2011.03.013

Energy Information Administration. 2015. Petroleum and other liquids [online], [cited November 18, 2015]. Available from Internet: http://www.eia.gov/dnav/pet/pet_pri_spt_s1_d.htm

Faff, R. W.; Brailsford, T. J. 1999. Oil price risk and the Australian stock market, Journal of Energy Finance and Development 4(1): 69-87. https://doi.org/10.1016/S1085-7443(99)00005-8

Freelunch. 2015. Free economic, demographic \& financial data [online], [cited November 18, 2015]. Available from Internet: www.economy.com/freelunch

Gal-Or, E. 2011. Pricing practices of resellers in the airline industry: posted price vs. name-yourown-price models, Journal of Economics \& Management Strategy 20(1): 43-82.

https://doi.org/10.1111/j.1530-9134.2010.00283.x

Granados, N.; Kauffman, R. J.; Lai, H.; Lin, H. 2011. The value to consumers of IT-supported à la carte pricing: an empirical test of the strategic decommoditization hypothesis, in Proceedings of the 44th Hawaii International Conference on System Sciences, IEEE Computer Society, 4-6 January, 2011, Washington, DC, USA. https://doi.org/10.1109/hicss.2011.438

Hendricks, K. B.; Singhal, V. R. 2003. The effect of supply chain glitches on shareholder wealth, Journal of Operations Management 21(5): 501-522. https://doi.org/10.1016/j.jom.2008.09.001

Hendricks, K. B.; Singhal, V. R.; Zhang, R. 2009. The effect of operational slack, diversification, and vertical relatedness on the stock market reaction to supply chain disruptions, Journal of Operations Management 27(3): 233-246. https://doi.org/10.1016/j.jom.2008.09.001

Hileman, J. I.; Stratton, R. W. 2014. Alternative jet fuel feasibility, Transport Policy 34: 52-62. https://doi.org/10.1016/j.tranpol.2014.02.018

Hoffer, G. E.; Pruitt, S. W.; Maurice Tse, K. S. 1996. U.S. International air route awards and shareholder wealth, Economics Letters 53(1): 75-81. https://doi.org/10.1016/S0165-1765(96)00896-8 
Kim, I. M.; Loungani, P. 1992. The role of energy in real business cycle models, Journal of Monetary Economics 29(2): 173-190. https://doi.org/10.1016/0304-3932(92)90011-P

Kumar, M. 2014. The impact of oil price shocks on Indian stock and foreign exchange markets, Money and Finance February: 57-88.

Lee, B. L.; Wilson, C.; Pasurka, A. 2015. The good, the bad, and the efficient: productivity, efficiency, and technical change in the airline industry, 2004-11, Journal of Transport Economics and Policy 49: 338-354.

Lu, W.-M.; Wang, W.-K.; Hung, S.-W., Lu, E. T. 2012. The effects of corporate governance on airline performance: production and marketing efficiency perspectives, Transportation Research, Part E: Logistics and Transportation Review 48: 529-544.

https://doi.org/10.1016/j.tre.2011.09.003

MIT Airline Data Project. 2015. Airline data project [online] [cited November 18, 2015]. Available from Internet: http://web.mit.edu/airlinedata/

Mulhall, R. A.; Bryson, J. R. 2014. Energy price risk and the sustainability of demand side supply chains, Applied Energy 123: 327-334. https://doi.org/10.1016/j.apenergy.2014.01.018

Nandha, M.; Brooks, R.; Faff, R. 2013. Oil, oil volatility and airline stocks: a global analysis, Accounting and Management Information Systems 12(2): 302-318.

Naumann, M.; Suhl, L. 2013. How does fuel price uncertainty affect strategic airline planning?, Operational Research 13(3): 343-362. https://doi.org/10.1007/s12351-012-0131-0

O’Neill, T. J.; Penm, J.; Terrell, R. D. 2008. The role of higher oil prices: a case of major developed countries, Research in Finance 24: 287-299. https://doi.org/10.1016/S0196-3821(07)00211-0

Park, J.; Ratti, R. 2007. Oil price shocks and stock markets in the U.S. and 13 European countries, Energy Economics 30(5): 2587-2608. https://doi.org/10.1016/j.eneco.2008.04.003

Rogoff, K. 2006. Oil and the global economy [online], [cited 30 February 2015]. Harvard University Working Paper. Available from Internet: http://www.nes.ru/public-presentations/Papers/ Oil\%20and\%20the\%20Global\%20Economy_Rogoff_v2.pdf.

Sadorsky, P. 2001. Risk factors in stock returns of Canadian oil and gas companies, Energy Economics 23: 17-28. https://doi.org/10.1016/S0140-9883(00)00072-4

Tavassoli, M.; Faramarzi, G. R.; Saen, R. F. 2014. Efficiency and effectiveness in airline performance using a SBM-NDEA model in the presence of shared input, Journal of Air Transport Management 34: 146-153. https://doi.org/10.1016/j.jairtraman.2013.09.001

Treanor, S. D.; Simkins, B. J.; Rogers, D. A.; Carter, D. A. 2014. Exposure, hedging, and value: new evidence from the US airline industry, International Review of Financial Analysis 34: 200 211. https://doi.org/10.1016/j.irfa.2014.04.002

Turner, P. A.; Lim, S. H. 2015. Hedging jet fuel price risk: the case of U.S. passenger airlines, Journal of Air Transport 44-45: 54-64. https://doi.org/10.1016/j.jairtraman.2015.02.007

Wooldridge, J. M. 2002. Econometric analysis of cross section and panel data. Cambridge, MA: MIT Press, 282-283.

Barbara GAUDENZI is Associate Professor at the Department of Business Administration at the University of Verona (Italy). She is Director of the Post Graduated Course in Risk Management, and Director of the Master in Supply Chain Management at the University of Verona (Italy). Her research interests focus on risk management, logistics management and commodity price risk management.

Alessandro BUCCIOL is Associate Professor at the Department of Economics at the University of Verona (Italy) and Adjunct Professor of Econometrics, University of Padova, Italy.

His research interests span across household finance, savings decisions, behavioral economics, economic incentives, public finance, and in general applied micro-econometrics. 